\title{
German Political Foundations in Central Asia: Promoting Democracy through Civil Society
}

\author{
Chiara Pierobon, $\mathrm{PhD}$ \\ Bielefeld University, Germany \\ Center for German and European Studies (CGES/ZDES)
}

\begin{abstract}
The paper offers a critical analysis on the role of German political foundations as actors in democracy assistance and is aimed at detecting similarities and divergences in their operation with the civil society of the region. To this end, the article investigates the concrete programs implemented by two major German foundations - the Friedrich Ebert Foundation (FES) and the Konrad Adenauer Foundation (KAS) - in Central Asia, with emphasis on the specific case study of Kyrgyzstan.
\end{abstract}

Keywords: German political foundations, democracy assistance, civil society, social capital, democratization in Central Asia

\section{Introduction}

In the past decade, the promotion of democracy in third countries has become an essential element of the European Union's external policies and development agenda wherein democracy is seen as necessary condition for ensuring inclusive and sustainable development. A role of pivotal importance in the development process has been assigned to civil society conceived as the primary actor in sustaining the democratization process by ensuring grassroots political participation and holding the governments accountable. This applies also to German political foundations (in German parteinahe Stiftungen or politische Stiftungen) that are involved in the promotion of democracy abroad through the empowerment of civil society. Their agenda includes political education aimed at the strengthening of information and press freedom, the promotion of the administrative capacity for local (self-) government and the improvement of the rule of law. Noteworthy, although they are funded through federal state budget, the politische Stiftungen operate independently from the German government and are free to choose their priorities and fields of involvement.

The paper focuses on the role of German political foundations as actors in democracy assistance in Central Asia and on detecting similarities and divergences in their operation with the civil society of the region. For this scope, the paper investigates the concrete programs implemented by two major German foundations - the Friedrich Ebert Foundation (FES) and the Konrad Adenauer Foundation (KAS) - in Central Asia, with emphasis on the values and systems of meaning spread through their activities. Particular attention is given to the conceptualizations of civil society and of its contribution to democracy in which the initiatives carried out with the support of FES and KAS are grounded. It also looks at the mechanisms through which they influence the operation of civil society and the opportunities which civil society organizations have at their disposal to safeguard their autonomy and independence. In addition, the paper delves into the ways in which these two parteinahe Stiftungen interact with the government, the media sector and the public in the specific case study of Kyrgyzstan.

\section{German Political Foundations: an historical overview}

The establishment of German political foundations in the post-war period should be interpreted as a reaction to the experience of the Weimar Republic (1918-1933) and its failure. More precisely, in the aftermath of World War II, foundations were established or re-established by political parties with the aim of re-building the democratic institutions that went destroyed in the time of National Socialism and of stabilizing the young democracy of the Federal Republic of Germany through the creation and spread of a democratic political culture. As a matter of fact, the existence and work of these organizations find their constitutional basis in the German Basic Law (Grundgesetz) approved in 1949 and, more 
specifically, in Article 5 on freedom of expression, in Art. 9, par. 1 on freedom of association and in Art. 12, par. 1 on professional freedom.

In the first two decades after the end of the war, four political foundations - Friedrich Ebert Foundation (FES), Friedrich Neumann Foundation (FNS), Konrad-Adenauer Foundation (KAS) and Hanns Seidel Foundation (HSS) - received funding from the West German treasure for the conduction of activities in the field of democratic education in Germany. Since 1962, German political foundations have received government funds also for the conduction of projects in developing countries in the field of socio-political education and support for social structures. The engagement of these organizations in international political projects should be contextualized in West Germany's attempt to counteract communist influence in the Third World. It is noteworthy in this regard that "at a time when memories of the Nazi era were still fresh, payment were thought to be more acceptable abroad if they came in the name of political parties [and political foundations] rather than from the German government" (Pinto-Duschinsky, 1991: 34). The function of German political foundations in international cooperation was refined through the joint declaration with the German Ministry of Economic Development and Cooperation (BMZ) of 1971 where it was stated that "the political foundations support their partners in developing countries who are striving to meet the aims of the United Nations' Universal Declaration of Human Rights by taking effective structural action to promote social justice, encourage wider political participation and increase their countries' economic independence. [...] The main focus of this development policy is on helping disadvantaged sectors of society to help themselves"1.

\section{German political foundations: current developments}

Nowadays, German political foundations are assigned a role of pivotal importance in the development of democracy and the strengthening of civil society inside and outside of Germany ${ }^{2}$. As private, non-profit entities under German law, they are non-governmental organizations (NGOs) which are economically and organizationally independent from the parties to which they are ideologically affiliated. Altogether, there are six national political foundations active in Germany: the Friedrich Ebert Foundation (FES) which is related to the Social Democratic Party, the Friedrich Neumann Foundation (FNS) which is linked to Free Democratic Party, the Hanns Seidel Foundation (HSS) which is closed to the Christian Social Union, the Henrich Böll Foundation (HBS) which is related to the party "The Greens", the Konrad-Adenauer Foundation (KAS) which is affiliated to the Christian Democratic Union, and the Rosa Luxemburg Foundation (RLS) which is related to the Party of Democratic Socialism³.

Although they act independently from the government, they are mainly (about $90 \%$ ) supported by the federal state budget (Mohr, 2010: 23; 25). The annual support to political foundations on behalf of federal ministries is decided by the Budget Committee (Haushaltsausschuss) of the German parliament (Bundestag) and the distribution of the resources to the foundations is proportional to the weight of their affiliated political parties. State budget is also available for socio-political and democratic education in forms of "global grants" awarded by the Federal Ministry of Interior. In addition, political foundations can finance their scholarship programs and activities in the field of development cooperation with resources made available by the Federal Ministry for Economic Cooperation and Development (BMZ), Federal Foreign Office and other ministries such as the Federal Ministry of Education and Research. As a matter of fact, between 2005 and 2014, the federal budget allocated to German political foundations registered an increase of about $50 \%$, reaching the amount of 466 million Euro in 2014. At present (2016), the FES received $30.29 \%$ and the KAS $29.57 \%$ of the overall federal budget; they are followed by the HBS with $10.51 \%$, the FNS with $10.21 \%$, and the HSS and the RLS with $9.71 \%$ respectively 4 .

The increase of the budget available to German political foundations has gone hand in hand with the increasingly important role assigned to them as foreign policy tools. In particular, their engagement in the promotion of democracy abroad has been focused on strengthening key democratic institutions such as parliaments, political parties and an independent judiciary as well as the promotion of good governance through the participation of civil society. As envisioned by the BMZ, a central objective of German political foundations abroad shall be the strengthening of civil society organizations in developing and transition countries and their involvement in transnational structures and global policy networks as well as in international and global dialogue processes on development-related issues. The political relevance of the international

\footnotetext{
1 http://www.kas.de/wf/doc/kas_7742-1442-1-30.pdf?120928104105

2 http://www.bmz.de/de/ministerium/wege/bilaterale_ez/akteure_ez/polstiftungen/

${ }^{3}$ Noteworthy, every party which has been represented in the German parliament for at least two consecutive legislative sessions is authorized to establish an affiliated foundation.

${ }^{4}$ http://www.kas.de/wf/de/71.3712/
} 
engagement of these organizations is testified by the police inspections of the bureaus of the Friedrich Ebert Foundations and the Konrad Adenauer Foundation taking place in St. Petersburg and Moscow in 2013. These episodes can be interpreted as an evidence of the influence attributed to German political foundations and of the difficulties that they might face when they operate in environments which are not so conductive for civil society development.

In the next section of the paper, the engagement of the foundations in development assistance will be investigated more in details, taking into consideration the involvement of the Friedrich Ebert Foundation and the Konrad Adenuaer Foundation in Central Asia. The analysis will be enriched with the empirical data collected through semi-structured interviews with representatives of the selected foundations as well as with partners and implementers of their projects in Kyrgyzstan.

\section{Friedrich Ebert Foundation (FES)}

The FES is the oldest German political foundation and is grounded in the basic values of social democracy: i.e., freedom, justice and solidarity. As published on its web presence, the organization sees itself as part of the social democratic community of values and the trade union movement in Germany and the world and, through its work, it seeks to help people in shaping their societies and in fighting for social democracy ${ }^{1}$. The central task of the FES consists of political education and consulting; as international think tank, it endeavors in offering an impetus for a policy of social democracy not only in Germany but worldwide. With a budget of 152 million Euro in 2014, and 660 employees and 150 offices in Germany and abroad in 2015, the FES represents the biggest foundation in the country.

The FES is active in four Central Asian republics with exception of Turkmenistan and is present in the region through its bureaus in Almaty and Astana (Kazakhstan), in Bishkek (Kyrgyzstan), in Dushanbe (Tajikistan) and in Tashkent (Uzbekistan).

Civil society is conceptualized by the FSE as the space between the state, the market and the private sphere which is made up by NGOs, volunteers, neighborhood and community groups and other associations ${ }^{2}$. A central aim of the foundation is to intensify the cooperation between the state, the market and civil society seen as a fundamental element of the modern state. Therefore, the FSE seeks to strengthen civil society in Central Asia by providing it with the necessary freedom to operate as powerful and independent actor and by promoting a public dialogue on the importance of $\mathrm{CSOs}^{3}$.

While the empowerment of civil society is one of the main declared objectives of the foundation common to the whole region, differences in its agenda emerge when looking at its engagement in the single Central Asian republics reflecting the socio-economic and political peculiarities of the target countries. For instance, the involvement of the FES with Kazakh civil society is linked to the state's attempt to diversify its economy which, at the moment, is mainly based on the export of natural resources such as petroleum. In this framework, the foundation is engaged in promoting the social and political conditions of the labor market by assisting trade unions in improving the existing mechanisms for solving labor disputes. At the same time, it supports Kazakh NGOs by fostering the cooperation between the government and the non-profit sector and by supporting the latter to become independent from foreign donors. Remarkably, the independence from the international community is seen as a necessary condition for Kazakh civil society to become an autonomous force and follow its own agenda.

In Uzbekistan, the engagement of the foundation with civil society is focused on promoting a strong and independent nonprofit sector with an emphasis on enhancing the participation of women in the economic and political life. Hereunto the foundation seeks to improve the framework in which Uzbek CSOs operate also in collaboration with government bodies. In this framework, two public events were organized in 2015 to foster the exchange on civil society developments between Uzbekistan and Germany and, more precisely, to familiarize Uzbek civil society with the German experience. During the seminars that saw the participation of the National Association of NGOs and the Academy of Public Administration the German model of civil society was presented and a critical overview of the its current challenges was offered also through a comparison with the Uzbek case.

Similarly, the FSE involvement with civil society in Kyrgyzstan and Tajikistan is focused on gender awareness and women inclusion in political processes as well as on the empowerment of younger generations. More specifically, in Kyrgyzstan

\footnotetext{
1 https://www.fes.de/de/stiftung/ueber-die-fes/

$2 \mathrm{http}: / /$ www.fes-centralasia.org/de/themen/zivilgesellschaft.html

3 lbid.
} 
the foundation aims at promoting democratic institutions and a democratic political culture through the development of a diverse civil society. An example of the Foundation's work in the field of women empowerment in Kyrgyzstan is offered by the Women's Forum which was organized in 2015 in occasion of the 90th anniversary of the Kyrgyz women's movement in collaboration with the Rosa Otunbajewa Foundation. The event brought together more than 1200 activists from all the regions of the country providing a platform for debating on political and economic participation of women as well as their access to justice and education. As reported by the foundation itself, the forum enabled the formulation of gender specific demands at a peculiar time characterized by the parliamentary primaries. In addition, a Youth Leadership Project was conducted in Kyrgyzstan between 2012 and 2014 and which was aimed at fostering the participation of young people in social and political life. The project, which was implemented with the collaboration of the Institute for Youth Development, provided young activists with capacity-building seminars focused for instance on project management skills for social entrepreneurship. The Youth Leadership Project and the engagement of the FES with Kyrgyz Citizen media will be descried in more detail in the next section.

\subsection{FES and the empowerment of civil society in Kyrgyzstan}

The FES has been working for several years with the Kyrgyz youth by providing capacity buildings to youth civil society organizations and centers; the latter are state-supported institutions created by Akimats at city- and town-level. The foundation describes its engagement in this field as successful as testified by the establishment of the Confederation of Youth Organizations (Verband der Jugendorganisationen) in 2012 which nowadays comprises 23 groups ${ }^{1}$. In the same year, the FES introduced the Youth Leadership Project which was conducted in collaboration with the Institute for Youth Development and which was aimed at "creating conditions for successful and efficient fulfillment of youth organizations, youth capacity building and its application towards innovation development of the social sphere and civil society in Kyrgyzstan"2. More specifically, the project was focused on attracting young people to participate in decision-making processes and raising their awareness on the importance of youth participation in solving the problems surrounding them ${ }^{3}$. Therefore, in the framework of the Youth Leadership Program, capacity building activities were offered to young NGO representatives through which they could increase not only their knowledge on youth issues but also their managerial skills.

In addition, since 2000 , the FES has been involved in the professionalization of independent media and, more precisely, in the development of citizen media by providing non-professional journalists with thematic trainings. These seminars are focused on political topics such as political parties in Kyrgyzstan, gender politics and the meaning of parliamentary republic according to the western tradition ${ }^{4}$. The initiative is conducted in collaboration with the Deutsche Welle Academy and the Confederation of Citizen Media (Verband der Bürgermedien) which comprises 27 members including radio and multimedia in the region. The final goal consists in the establishment of a one-hour weekly broadcast on current political themes (Politische Stunde) made by ordinary citizens for ordinary citizens. In the framework of this project, study trips to Germany were organized for the most engaged people's correspondents (Volkskorrespondenten) to familiarize them with the German experience and best practices.

\section{Konrad Adenauer Stiftung (KAS)}

The KAS is grounded in the values of peace, freedom and justice and is particularly concerned with the consolidation of democracy, the promotion of European integration, the intensification of transatlantic relations and development cooperation. As think tank and consulting agency, the KAS endeavors in providing scientifically-based analysis of political activity $^{5}$. The KAS Academy in Berlin together with conferences and seminars it organizes are presented by the foundation as a venue for exchange on future-relevant issues pertaining politics, economics, religion, society and science. Its scholarship programs are aimed at supporting materially and ideally talented young people from Germany, Central and Eastern Europe and other developing countries ${ }^{6}$. With a budget of 140 million Euro in 2014, 640 employees and 70 offices and projects in 120 countries, the KAS is the second largest foundation in Germany.

\footnotetext{
1 Interview conducted with FES Head of Office in Kyrgyzstan (Bishkek, November 2016)

2 Interview conducted with two representatives of Institute for Youth Development (Bishkek, November 2016)

3 lbid.

${ }^{4}$ Interview conducted with FES Head of Office in Kyrgyzstan (Bishkek, November 2016)

${ }^{5}$ http://www.kas.de/wf/de/71.3628/

${ }^{6}$ lbid.
} 
The KAS is present in Central Asia through its bureau in Astana (Kazakhstan) and the Regional Project Central Asia based in Tashkent (Uzbekistan). The engagement of the foundation in the region is focused on education and, especially, on political education, media development and the strengthening of parliamentary institutions and local self-governments.

In the field of education, the KAS supports young talented people in Kazakhstan and Kyrgyzstan through the Sur-Place Scholarship program providing a five-month-financial support to students in social sciences and humanities. The program is described by the foundation representative in Kazakhstan as a way to serve the process of democratization and development of civil society ${ }^{1}$. Besides the scholarship granted, the KAS organizes events and conferences for current participants and alumni of the Sur-Place initiative, during which politically relevant topics are discussed. The aim of these initiatives is to offer young people a venue where to learn how to build up their own mind and to voice their opinions ${ }^{2}$. The attendees are also offered professionalizing workshops on how to plan their future career; as a matter of fact, as reported by one of the KAS representatives, many alumni occupy higher position in the public (at the ministerial level) and private sector.

The foundation's involvement in Central Asia comprises activities in the field of media development and the professionalization of journalists aimed at increasing the reliability of and trust in the media. To this scope, in the past two years, seminars were held in Uzbekistan to foster the development of the media landscape in the country in partnership with the National Association of Electronic Mass Media in Uzbekistan; a focus on energy and environment-related issues characterized these capacity building activities. Workshops were offered to Uzbek journalists focused on how to develop a youth-oriented news broadcasts using modern methods and international standards which was facilitated by the know-how exchange with media experts from Germany. Similarly, seminars were organized in Uzbekistan on how to produce social advertisements for electoral campaigns and Uzbek journalists took part in a study exchange program in Germany where they visited and learnt from the experience of German public and private channels. Noteworthy, the work of the foundation in the field of media development in Kazakhstan is conducted in close cooperation with the International Center for Journalism Medianet whose declared mission is to support civil society development in Kazakhstan and Central Asian countries through the empowerment of independent and objective mass media, to support public organizations and protection of human rights and fundamental freedoms ${ }^{3}$.

In addition, the foundation is involved in strengthening parliamentary institutions and local self-governments in Central Asia. For instance, in the past years, KAS has offered several conferences and experts' roundtables on topics such as the development of a multi-party system and party competition in Kyrgyzstan and Uzbekistan and the importance of the parliament as a public control instrument to ensure the protection of civil and political rights of ordinary citizens. Likewise, seminars were conducted in Tajikistan to discuss the development of parties and parliamentarism in partnership with the National Association of Independent Mass Media in Tajikistan. Furthermore, workshops on the fundamentals of localgovernment were held in Kazakhstan which were attended by members of the parliament and the local administration. These events were organized in collaboration with international partners such as the Organization for Security and Cooperation in Europe and the National Democratic Institute and national partners such as the Regional Policy and Local Self-Government Development Department of the Ministry of National Economy and the Rosa Otunbajewa Foundation.

\subsection{KAS and the empowerment of civil society in Kyrgyzstan}

A very good example of the KAS' engagement in promoting democracy through the strengthening of civil society in Kyrgyzstan is provided by the project "Fostering and Monitoring of the Education Reforms in the Kyrgyz Republic". This initiative is implemented by the foundation with the assistance of the local organization BIOM Ecological Movement and the financial support of the European Union (EU); it has a duration of 1,5 year - between January 2015 and June 2017 and an overall budget of 500.000 EUR.

The main objective of the project is to improve the work of the Public Advisory Council of the Ministry of Education and Science (EPAC). Remarkably, the Public Advisory Councils (PACs) were established by law in 2014 to monitor the activities of public authorities and to contribute to the decision-making process concerning the formation and implementation of public policy. The above-mentioned project is focused on the work of the EPAC and, more precisely, on improving its capacity of

\footnotetext{
1 http://www.kas.de/kasachstan/de/about/

2 Interview conducted with the representative of the KAS in Kazakhstan (Astana, June 2014)

${ }^{3} \mathrm{http}: / /$ www.kas.de/kasachstan/en/about/partners/
} 
monitoring the education reform process and of representing public views on education issues. To this scope, trainings are offered to the members of the EPAC and representatives of civil society to improve their capacity to design and implement public policy and to increase the understanding of the education reform process by looking also at best practices coming from the EU. In addition, new mechanisms of exchange and interaction between EPAC, civil society and media are established through which civil society representatives can be involved in consultation activities and mass media can be informed on the education reform taking place in the country. As reported by the implementing organization in this regard, the project will provide a platform for a structured dialogue between the government and civil society through which the latter will be involved in consultation, policy-making, and policy implementation processes in the educational field. Through the project, the transparency and accountability of the government will be enhanced and this will then contribute to the strengthening the democratic foundation of society itself ${ }^{1}$.

\section{Concluding remarks}

The paper was focused on the work of German political foundations in Central Asia. After a brief introduction on their history, development and mission, the article described the concrete engagement of the two major German political foundations the FES and the KAS - in Central Asia. The analysis was enriched with empirical data collected on the ground during a fieldwork taking place in Kyrgyzstan between October and November 2016. Since the study is still a work in progress, at this point only a few and very general concluding remarks can be offered to the reader.

As showed by this preliminary analysis, both the Friedrich Ebert Foundation and the Konrad Adenauer Foundation attribute to civil society a role of pivotal importance in the process of democratization and seek to strengthen the participation of (civil) society in the decision-making process. The foundations are active in the region as norm diffusers and, through their activities and seminars, contribute to the spread of similar representations and systems of meaning related to the role of civil society and media as well as the social, political and economic rights to which specific groups of the population (such as youth and women) should be entitled. Noteworthy, the German experience and best practices are used as a point of reference and as a model by both foundations.

Nonetheless, interesting divergences emerge if we look at the strategies adopted by the politische Stiftungen in Kyrgyzstan. For instance, the KAS' support to the youth takes place especially through the Sur-Place Scholarship program and a series of conferences and seminars addressed to individuals. On the contrary, the FES prefers to work with youth civil society organizations and promote youth empowerment by strengthening the organizational capacity of the groups working in this field. In addition, whereas the FES' initiatives are mainly addressed to civil society representatives and ordinary people (especially women and youth), the capacity-building activities of the KAS include also parliamentarians, local authorities and government bodies. Here the main difference characterizing the engagement of the two foundations with civil society come to light. Indeed, the work of the FES tends to focus on the empowerment of different civil society groups and representatives especially at the local level and in remote areas of the country to ensure the representation of pluralistic and diverse interests in the decision-making process. Conversely, the KAS is engaged in establishing structured channels of interaction between the non-profit sector and the state through which monitoring and consultation processes can take place at the government level. Therefore, both the foundations are active in Kyrgyzstan as infrastructure builders. However, whereas the FES is more focused on the creation of "bonding" social capital (Putnam 2000) strengthening civil society by building or reinforcing relations inside the non-governmental sector, the KAS supports civil society through the creation of "bridging" social capital (Ibid.) linking state with non-state actors.

\section{List of Acronyms}

$\mathrm{BMZ}$

Federal Ministry for Economic Cooperation and Development

CSO

$$
\text { Civil Society Organization }
$$

EPAC

Council of the Ministry of Education and Science

EU

European Union

FES

Friedrich Ebert Foundation

\footnotetext{
1 Interview conducted with BIOM director and project implementer (Bishkek, November 2016)
} 


$\begin{array}{ll}\text { FNS } & \text { Friedrich Neumann Foundation } \\ \text { HSS } & \text { Hanns Seidel } \\ \text { HBS } & \text { Henrich Böll Foundation } \\ \text { KAS } & \text { Konrad-Adenauer Foundation } \\ \text { NGO } & \text { Non-Governmental Organization } \\ \text { PAC } & \text { Public Advisory Council } \\ \text { RLS } & \text { Rosa Luxemburg Foundation }\end{array}$

\section{Bibliography}

[1] Mohr, Alexander, 2010. The German Political Foundations as Actors in Democracy Assistance. Boca Raton / Dissertation.com

[2] Pinto-Duschinsky, M. 1991. "Foreign political aid: the German political foundations and their US counterparts", in International Affairs, Vol. 67(1), pp. 33-63.

[3] Putnam, R.D. 2000. Bowling Alone: The Collapse and Revival of American Community. New York: Simon \& Schuster.

[4] http://www.kas.de/wf/doc/kas_7742-1442-1-30.pdf?120928104105 (Last accessed on 29. August 2016).

[5] http://www.bmz.de/de/ministerium/wege/bilaterale_ez/akteure_ez/polstiftungen/ (Last accessed on 29. August 2016).

[6] http://www.kas.de/wf/de/71.3712/ (Last accessed on 29. August 2016).

[7] https://www.fes.de/de/stiftung/ueber-die-fes (Last accessed on 29. August 2016).

[8] http://www.fes-centralasia.org/de/themen/zivilgesellschaft.html (Last accessed on 29. August 2016).

[9] http://www.kas.de/wf/de/71.3628/ (Last accessed on 31. August 2016).

[10] http://www.kas.de/kasachstan/de/about/ (Last accessed on 31. August 2016).

[11] http://www.kas.de/kasachstan/en/about/partners/ (Last accessed on 31. August 2016).

[12] Interview conducted with the representative of the KAS in Kazakhstan (Astana, June 2014)

[13] Interview conducted with FES Head of Office in Kyrgyzstan (Bishkek, November 2016)

[14] Interview conducted with two representatives of Institute for Youth Development (Bishkek, November 2016)

[15] Interview conducted with BIOM director and project implementer (Bishkek, November 2016) 
